\title{
A qualitative study of factors influencing service-learning implementation in vocational education field of Pakistan: Teachers' perspectives
}

\author{
Iqbal Ahmed $^{1} \mid$ Muhammad Saeed $^{* 2} \mid$ Zahid Ullah ${ }^{3}$
}

1. Department of Education, Faculty of Social Sciences, University of Malakand, Chakdara, Pakistan.

2. Department of Global \& Social Studies, King Fahd University of Petroleum \& Minerals, Saudi Arabia.

3. Department of Education, Faculty of Social Sciences, International Islamic University, Pakistan.

* Correspondence Emails: msaeedpk@kfupm.edu.sa | saeeddir@gmail.com

\begin{abstract}
Service-learning is an emerging pedagogical method generating effective outcomes. However, its long-term outcomes are contingent on plausible planning, realistic target designing, and pragmatic execution and implementation. This study, drawing on elementary school teachers' views from the Punjab regions of Pakistan, attempts to explore the factors influencing service-learning implementation in the vocational field. Data were collected through semi-structured interviews from 30 teachers from different regions of the Punjab province who had participated in servicelearning projects. Study samples were selected through the purposive sampling technique. Thematic analysis technique was used for data analysis. The analysis process included data coding, categorizing, and clustering the categories into themes. The findings showed that planning, training and orientation, student placement, duration, collaboration, and reflection were major influencing factors of service-learning implementation in vocational education in Pakistan.
\end{abstract} Article History

Received:

January 9, 2021

Last Revised:

March 31, 2021

Accepted:

April 9, 2021

Published:

April 14, 2021

Keywords: service-learning, vocational education, elementary education, civic service, pedagogy, outcomes, teachers' experiences, education in Pakistan.

\section{How to Cite:}

Ahmad, I., Seed, M., \& Ullah, Z. (2021). A qualitative study of factors influencing service-learning implementation in vocational education field of Pakistan: Teachers' perspectives. Liberal Arts \& Social Sciences International Journal (LASSIJ), 5(1), 55-74. https://doi.org/10.47264/idea.lassij/5.1.5

\section{Publisher's Note:}

IDEA PUBLISHERS (IDEA Journals Group) stands neutral with regard to the jurisdictional claims in the published maps and the institutional affiliations.

Copyright: () 2021 The Author(s), published by IDEA PUBLISHERS (IDEA Journals Group). This is an Open Access article published under the Creative Commons Attribution-NonCommercial 4.0 International License (http://creativecommons.org/licenses/by-nc/4.0/) 


\section{Introduction}

In the past three decades, service-learning has tremendously grown into a popular pedagogy. For example, it has been identified as one of the top high-impact teaching and learning practices by the American Association of Colleges and Universities (Horning et al., 2020). Moreover, around the world, educational institutions are increasingly embracing service-learning as a teaching and learning approach (Blakey et al., 2015; Jacoby, 2014). It effectively connects academic content with real-life experiences which never happens in a traditional classroom environment (Brownell \& Swaner, 2010; Jerome, 2012). It is a positive practice for engaging youth in the community for promoting learning and a sense of civic service (Butin, 2010; Lieberman, 2014). Service-learning effectively prepares young people for the workplace, inculcates civic responsibilities (Galvan et al., 2018; Huda et al., 2018; Bringle et al., 2012), and furnishes leadership capacities (Robinson \& Gottlieb, 2002; Lambright, 2008). It is in this sense that many educators, administrators, and policymakers are considering service-learning as an extremely important strategy for youth development (Deeley, 2010; O'Grady, 2014).

Service-learning is beneficial for students, faculty members, academic institutions, and communities (Bringle \& Hatcher, 1995; Butin, 2010). Students find the wider opportunity of learning through gaining knowledge and skills, interpersonal and social skill development, and self-confidence (Denby, 2008; Falk, 2012; Trigos-Carrillo et al., 2020). They also get more knowledge of academic materials and their communities (Phillips, 2011). The service experience can also be used by faculty members to increase the quality of their teaching by finding opportunities for research and professional development (Butin, 2010, 2006). The community also receives many benefits in the form of valuable service and institutional support. The educational institutions reap the benefits of service-learning by developing an improved relationship with communities (Sangpikul, 2017).

However, service-learning implementation is a complex activity (Salam et al., 2019), influenced by multiple factors (Lee et al., 2018), ranging from academic to institutional (Butin, 2010; Lambright \& Lu, 2009; Rue, 1996; Zhang et al., 2011). On many occasions, servicelearning activity started strong but eventually weakened and failed due to poor assessment of the issues associated with its design and implementation (Bringle \& Hatcher, 2002; Wade, 2008; Zhang et al., 2011). It is necessary to identify and redress these influencing factors for better implementation of the service-learning program (Butin, 2010; Lambright \& Lu, 2009; Zhang et al., 2011). There is no single service-learning model that helps in implementing the service-learning experience because different administrative issues and factors always underpin the process of implementation (Playford et al., 2019). This, we argue, is largely true in the case of Pakistan. In this regard, we agree with Rue's (1996) views and identification of the issues that underpin the process of service-learning operations. These include a lack of understanding about community resources, political dynamics, culture, and key constituencies, and proper management of the human resources. Hence, given the complexity of the nature of service-learning, drawing on Berman's (2006) assertion, we opine that executors must chalk out and take into consideration the potential issues before embarking on or implementing service-learning.

\subsection{Factors influencing the service-learning implementation: An overview}

Studies suggest that for achieving the goals of service-learning, all stakeholders should work together and collaborate (Salam et al., 2019, Jacoby, 2014; Rue, 1996). In this sense, it is 
imperative that before the placement of students, it is quintessential to evaluate and assess the placement site and its suitability for service. This plays a key role in the successful placement of students (Butin, 2010). Further, research studies reveal that the success and sustainability of the service-learning program are intertwined with effective administration, monitoring, and leadership (Lambright \& Lu, 2009). Adding to it, students' placement is also considered an essential element of the service-learning program. Thus the placement of students should be done in collaboration with the community, consultation with faculty and students (Lambright \& Lu, 2009). However, on the contrary, many studies (as been discussed in the proceeding sections) have noted the lack of management support and security for students during the service activity in the field. Similarly, less effective collaboration between the community and Vocational Training Institutes (VTIs) have been documented on service-learning implementation. Consequently, this situation led to a decreased collaboration at all levels and the least community motivation in-service activity. Further, the lack of community interest in service activities could also be due to the unclear orientation of the community because of the poor collaboration.

Besides, the implementation of service-learning is often influenced by service duration, intensity, site placement, financial resources, age, and gender (Lambright \& Lu, 2009). Similarly, it has been noticed that service-learning implementation has also greatly influenced by an assessment of the institution, community contexts, development of program frameworks, human and financial resource management, designing the implementation, planning, program evaluation, risk management, and transportation matters (Lambright \& Lu, 2009). It is imperative to note that as per many studies there is no single correct model for implementation of service-learning because different administrative issues always underpin the process of implementation (Lambright \& Lu, 2009). So service-learning must be designed and implemented bearing in mind the situational conditions, cultures, and other objective conditions (Butin, 2010; Rue, 1996). Additionally, service-learning duration spanning a month has more benefits for students. Contrarily, it has been observed that most of the existing service-learning activities have less duration. In some service-learning, students are allowed to participate in planning, preparation, and decision-making. However, some are narrow in scope where students only pick trash from outside which negatively affects the implementation process (Johnson et al., 2019).

\subsection{The service-learning program implementation: The context of Pakistan}

Researchers believe that the education system of Pakistan is theoretical, mismanaged, and does not improve the professional skills and civic abilities of students. The youth graduating from educational institutions, especially the vocational education field, are unskilled or semi-skilled (Akhtar et al., 2011; Uzair-ul-Hassan \& Noreen, 2013). In Pakistan, a service-learning program has been launched in all the vocational training institutes (VTIs) of the Punjab province. It aims to nurture the civic and professional employability skills of students. Further, it would not only engage students in solving social problems of the communities but would also make them active and responsible citizens that would contribute to the well-being of Pakistani society. The following guidelines are used for the implementation of service-learning in the VTIs: (1) selecting a problem by looking in the community and finding a problem that is neglected, (2) conducting research by asking and verifying from people about the problems, (3) developing list of possible solutions, (4) creating social acceptability, (5) identifying the opposition by finding out people who may oppose the service activity and interact with them carefully, (6) advertising for sharing the work on media, (7) raising resources, (8) implementing the 
suggested solutions, (9) doing reflection and, (10) celebrating after performing the service (PVTC, 2014).

The duration of the service-learning course is fifty hours, including 10 hours of actual classwork and 40 hours of fieldwork to serve society. The marks allocation is based on the criteria: $10 \%$ attendance, $10 \%$ unscheduled quizzes, $50 \%$ fieldwork, and $30 \%$ presentation of fieldwork by the students. The service activity is supervised by a faculty who supervise students in the field during the service-learning activity. Management of VTIs provides the direction for designing, planning, and service-learning implementation. Students are supposed to perform the service in the community under the supervision of faculty. Many societies around the world have integrated service-learning in their educational curricula. However, little is known what issues and factors influence the process of implementation (Rue, 1996; Berman, 2006; Butin, 2010). Also, it is still unclear how the issues of service-learning implementation are identified and addressed (Gershenson-Gates, 2012; Schamber \& Mahoney, 2008). Likewise, servicelearning has already been implemented in all vocational training institutes of Pakistan to achieve the goals of professional skills and civic development of students. However, studies have reported about civic skills deficiencies among students graduating from Pakistani vocational educational institutes. In the context of Pakistan, till now, it is unclear what factors are influencing the implementation of service-learning. Resultantly, educational institutes do not add that much value and failed to achieve the outcomes. In this paper, this issue has been explored from a faculty perspective, and recommendations are presented for better implementation of service-learning.

In summary, service-learning projects have been initiated in multiple contexts all over the world. However, these programs face many challenges ranging from designing to implementation, and therefore, it requires a plausible approach of redress (Jacoby, 1996; Rue, 1996). However, little attention has been paid to the factors influencing the process of its implementation in vocational education (Rue, 1996; Berman, 2006; Butin, 2010; Zhang et al., 2011). This implies that the issues of service-learning implementation need to be identified, categorized, and resolved for effective implementation (Gershenson-Gates, 2012; Schamber \& Mahoney, 2008). Moreover, the existing research on service-learning has mainly focused on exploring students' perspectives (Weiler et al., 2013) and teachers' perspectives have been mostly ignored. However, the latter seems worthy as they cater to the responsibility for implementing and institutionalizing the service-learning activity. Hence, data collected based on their feedbacks and experiences would provide a different and important dimension towards understanding the process of implementing service-learning and its dynamics in multiple educational and cultural contexts. This study therefore aimed at exploring teachers' perspectives on factors influencing service-learning implementation in vocational education field of Pakistan.

\section{Theoretical framework}

As an education method, service-learning owes to the constructivist and experiential learning theory of David Kolb. The constructivist paradigm considers education learning as an active and constructive process. This theory explains that students derive meaning and create new knowledge by applying their skills and knowledge in real-life contexts (Jacoby, 2014). Kolb's experiential learning model also terms learning as a constructive process in which students identify a problem, plan to solve it, apply the plan in a real-life situation, get the results and reflect on it. This cycle truly represents the nature of service-learning. Among many theorists 
of education, the educational thoughts of Dewey have greatly influenced the pedagogy of service-learning. His experiential educational philosophy provided a foundation for the development of the theory of service-learning. To him, one of the major aims of education is to produce good citizens (Salam et al., 2019). Similarly, service-learning also serves the same purpose and highly recommended. For example, as an experiential learning method, servicelearning nurtures civic abilities and skills in students (Michael et al., 2018). Profoundly, service-learning is grounded in the following theoretical foundations: a) experiential education and b) democratic education. The experiential learning theory of Kolb provides a clear theoretical framework for service-learning pedagogy. His model of learning is highly influenced by the educational philosophy of Dewey and Lewin (Halberstadt et al., 2019).

Learning style inventory is based on Dewey's emphasis on learning to be based on experience and Lewin's stress on a person's active involvement in learning. According to Kolb servicelearning includes the following cyclical stages: (a) concrete experience (when students are involved in a service activity, (b) reflective observation (when students discuss their service experiences with other classmates and teacher and then write down in a journal dairy, (c) abstract conceptualization (when students are involved in the interpretation of activities and understanding the relationship among them and critically analyzing the concepts, (d) active experimentation (when students are involved in the activity developing new understanding and predicting future actions. Students question their assumptions, beliefs, and practices in the process of learning. This implies that many factors influence the service-learning, particularly its implementation.

\section{Methodology of the study}

\subsection{Design of the study}

This study used a qualitative transcendental phenomenological approach. Phenomenology is a qualitative research approach that describes the meaning in a lived experience of a phenomenon from many individuals which is the case in this study on service-learning implementation experience (Creswell \& Clark, 2017). The main aim is to describe the commonalities in the experiences of the teachers through qualitative investigation. Its main focus is on the subjective descriptions given by the participants for generating an essence out of their lived experiences. The foundation of this study was formed by the interpretive paradigm that calls on participants to share their views based on their individual experiences and perceptions (Creswell \& Clark, 2017). The qualitative case study consists of a series of steps logically connected accounting for the perspectives of the research subjects and which are used for rigorous data collection and analysis (Phillips \& Burbles, 2000).

\subsection{The study sampling procedure}

Purposive criterion sampling was applied to identify study participants (teachers) who had already participated in the service-learning project implementation in vocational institutions in the different regions of Punjab. This type of sampling method helps create a homogenous sample of research participants who have different and similar experiences (Creswell \& Clark, 2017). The teachers were purposively sampled based on their experiences of participating in service-learning implementation (Hall, Chai et al., 2016). The participants were contacted through cover letters and consent forms to get their agreement to take part in the study. A sample of 30 participants (See Appendix 1) took part in the study. The participating teachers 
ranged from 1 to 3 years in terms of experience in service-learning implementation in vocational institutions in the Punjab province of Pakistan. The female teachers were contacted however they declined to participate in interviews for personal reasons owing to the cultural sensitives about women's participation and interviewing. Hence, we had no access to women's participants, they were excluded from the participants' list of the study.

\subsection{Data collection procedure}

The data collection process was conducted in different phases. First, a semi-structured interview protocol was developed. The interviews were conducted with the teachers in their classrooms. The interviews were audiotaped for maintaining the accuracy of the information. The interview protocol included six theme questions (See Appendix 2) about the implementation of service-learning projects and their different phases in vocational training institutes. Throughout the interview process, some probing questions and follow-up questions were also asked to further add to understanding as and when needed. This technique helped to encourage the participants to further elaborate and clarify their responses (Creswell \& Clark, 2017). Some more specific questions were also posed to the participants during the interview process in response to developing themes. The interviews were conducted by the first author personally, and immediately after every interview verbatim transcript were generated, in collaboration with the other co-authors, from the collected data. The data collection was completed in five months and came to an end upon the occurrence of saturation in data when there were no further themes and emergence of new information to add to the understanding of the phenomenon under study.

\subsection{Data analysis}

In this study, we used Moustakas's structural method of inductive data analysis based on the thematic analysis technique. Each transcript was read many times and memos were recorded along with highlighting the key concepts. After reading each transcript, all transcripts were read to highlight key concepts (Moustakas, 1994). We followed the following major steps in the analysis process. Firstly, we collected the statements and coded them with descriptive labels. Secondly, we reduced and eliminated some of the statements of the participants to understand the experiences of the participants and for abstracting and labelling the key statements. Thirdly, we clustered the related constituents together to group them. Then we thematically labelled each category. The coding process resulted in several categories of the invariant constituents of the experiences of the participants. We repeated this several times for further grouping and reducing the categories till all the constituents clustered and reduced to five themes related to the experiences of the participants. Fourthly, the themes were identified by reading and re-reading the transcripts to verify that the themes and the associated invariant constituents are clearly expressed and these well-matches with the statements of the participants. Later, we used these themes for constructing the textural-structural descriptions that were reflexive of the essence of participants' experiences. Finally, we narrated the extracted themes in texts. We also analyzed the codes later in detail and found no significant discrepancies in the coding. Through rigorous checking, we ensured the credibility of the findings and the interpretation of the data (Lincoln \& Guba, 1985). We emailed the final themes as well as some samples of the invariant constituents to the participants for their reviews to make sure it is reflexive of their views. The participants responded positively that themes were accurate reflections of their perspectives and experiences. 


\section{Results and findings of the study}

From the composite description of codes and categories, the essence of the common experiences of the participants was created in the formation of final themes which were selected for discussion based on interviews. From the participants' experiences of service-learning implementation, six themes emerged which include (1) planning, (2) duration, (3) training and orientation, (4) students' placement, (5) collaboration, and (6) reflection. Besides the following detailed analysis of each theme in the sub-sections, the table-1 at the end illustrates the major quotes that represent the perspectives of the research participants.

\subsection{Planning}

The participant teachers thought of planning an important element of service-learning implementation. They [teachers] described that in the planning stage all service-learning participants should participate. In the planning, they should set procedures for its implementation and should not work as recipients to work with students. They [participants] need to plan for effective engagement of students in the community site during servicelearning. Students must find the opportunity to become part of the decision-making or sharing their input during service-learning planning, they opined. Teachers expressed that their role was important for students' development during the service-learning particularly working with students as a coach. On the other hand, students could not play any role during the planning stage for service-learning. One of the teachers remarked:

They [students] look at their teachers for guidance. Hmmm! Sometimes they look confused but most of the time they look interested in the service-learning activity. If I say they are happy, I am wrong because they want to do more, like they wanted to share their ideas which might be useful for planning of the project which is not possible right now. (Respondent no. 8).

Most of the teachers believed that their participation in the service-learning planning was useful for guiding the students. However, they suggested that students should also be provided some form of participation in planning stage to improve their leadership skills. Some of the teachers expressed that they wanted to do more if the resources and time allowed including carrying out more discussion in the classroom on service-learning, exposing students to new forms of service-learning activity like digital or online service-learning, and so on. One teacher said:

I believe I would be able to bring more positive changes in the thinking of my students about community service through service-learning if I am allowed to introduce some innovations in my approach towards working with them [students]. (Respondent no. 11).

Other respondents [teachers] were of the view that more efforts were needed to make servicelearning implementation successful. This could be possible by inviting all the stakeholders including the key participants [students and community members] in the planning stage for service-learning in a broader sense rather than just inviting them as workers in the community site [students] to do community service: "Collaboration is the key to success in any human activity. It should be practiced throughout the service-learning right from planning to reflection. However, I do not think we are giving them [students and community] enough space in the planning for service-learning," said by respondent no. 21. 


\subsection{Duration}

Most of the teachers believed that duration was an important element of the service-learning project. Commenting on the importance of duration, a teacher stated:

You know, I understand that the time student spent in service-learning activity is more important than other things. (Respondent no. 6)

He believed that if the students are provided enough duration for performing the servicelearning activity, they [students] will learn effectively and achieve more success in their academic careers. Other teachers also expressed their views on increasing the existing duration for service-learning. They reckoned duration as an essential condition for the success of service-learning. They [teachers] pointed out that the existing duration was not sufficient. For example, one respondent mentioned:

Duration is really important for the success of service-learning. You see, it is something very essential. You know, if you allow students to participate in service-learning with flexible time, they [students] will get more chances for enhanced learning. (Respondent no. 23).

We observed that nearly all teachers thought that duration was important for offering students the opportunity to participate in service-learning in a relatively flexible way. They [teachers] felt that in the field students needed more time for interaction with community members and had to learn about community life. Other teachers believed that even if within the existing time students were doing their service-learning but it was not sufficient to do work in the community in a more open mind manner. Respondent no. 13 strongly believed that duration was an area worth mentioning on which the teachers and management should focus as it was directly related to the learning of students. He further mentioned that students must have full time for conducting service-learning: "It is an important area for better students' learning." Although most of the teachers expressed that duration was an important element of service-learning, the amount of time spent on service-learning. The teachers further expressed that the time for service-learning must be increased. For example, one of the teacher said:

I believe there must be enough time for students to spend in the field, i.e., between one to two hours a day. (Respondent no. 4).

\subsection{Training and orientation}

The participant teachers experienced service-learning without proper prior training and orientation. They [teachers] further expressed that students and community members had no training about service-learning. All teachers believed that prior training and orientation sessions regarding service-learning were essential for all stakeholders. However, due to the lack of it, many complications arose such as lack of student participation, low community motivation, and so on. For example, one teacher highlighted:

I think training on service-learning is very important. You see! Hmmm... students and teachers need to know how to interact with others in the community as it has a deeper impact on the success of the service-learning project. (Respondent no. 10). 
Teachers suggested that training needs to be provided to all participants that will result in an improved service-learning experience for students, teachers, and the community. Many teachers narrated that they received some training on service-learning but it was not sufficient to have fully understood the process of service-learning. For example, one teacher said:

I am aware that service-learning is a complicated activity. You know! I was very excited at the start...but it dropped later as I went through the ordeals of service-learning implementation without proper training. (Respondent no. 7).

Few teachers demonstrated a negative attitude towards the service-learning project as well, noticed it through their body expressions and tone. For example, one teacher told:

Service-learning is costly and more complicated as it is performed out of the classroom in the community where many cultural issues exist which need to be explored before starting a program. (Respondent no. 1).

Many teachers perceived themselves to be in difficulty supervising students in the field without proper training. Only one teacher believed that he was not facing any problem in servicelearning. According to him, everything was right, he said:

I think it is not a big deal to do service-learning as long as people are cooperative in the community. (Respondent no. 27).

All teachers followed the same service-learning curriculum approved for the vocational education system. However, they believed that it was not effective in improving students' learning. For example, one teacher mentioned:

I know we need to take students to the field for service-learning but it is not engaging...students and community people take less interest in the activity...I think the only reason is the lack of training and orientation related to the servicelearning project's importance and its implementation. (Respondent no. 3).

Similar views were shared by another teacher as well and he said:

There is less role for the community members in the service-learning activity... they only receive the service not as a participant but as a customer of service...hence you know they do not take interest. The same is with students. (Respondent no. 24).

\subsection{Students' placement}

Most of the teachers reported about students' placement without need analysis during servicelearning activity. Student's placement in the community site without proper homework and guidance led to service-learning failure, mentioned by one participant. Many teachers pointed out several challenges and issues in the community about student placement during servicelearning activities. They thought that community and field challenges should be identified and explored. This would influence the effective implementation of the service-learning activity as well as would help augment the chances of student development. Teachers expressed that student placement should be based on proper community participation, and providing students 
a thorough orientation about the community and its dynamics. Only then the chances of success of service-learning activity would increase. For example, one teacher remarked:

I have experienced that students are placed in the community site without proper analysis...even the community is not taken into confidence about the placement of students. (Respondent no. 13).

Some of the teachers mentioned the security, safety, and cultural differences as major challenges in the community. However, they opined that it is important to identify the contextual needs before sending students to the community site for service-learning. For example, one teacher stated:

I guess the community members will not cooperate until there are closer collaboration and understanding between the institutions and community on service-learning, I understand this, hmmm... we have not yet thought on this point. (Respondent no. 20).

Another teacher shared similar views and mentioned that community site analysis is essential before placement of students in service-learning. He said:

You know! In my experience, there are some points which must be taken into consideration before placement of students in the community such as cultural sensitivity, community members' engagement through orientation, security of students during service-learning." (Respondent no. 22).

The teachers suggested that placement of the students in the community site for servicelearning should be done after a thorough analysis of the community context, cultural orientations, security issues, and time frame. This will help students to get an inclusive insight into the community, anticipate the potential challenges, and prepare themselves for the execution of effective service-learning. We argue that the management of the institutes needs to underscore these needs before designing for implementation of service-learning and involving communities.

\subsection{Collaboration}

Teachers described that collaboration and cooperation were essential for the success of the service-learning activity. Collaboration was one of the key elements of service-learning projects. There is a need to develop a strong rapport and effective networking and links among all service-learning participants such as community, students, teachers, and institutions. For example, one teacher told:

Collaboration between communities and institutions during service-learning is extremely important. I have observed that there are plans but there is no lack of commitment and collaboration to implement the service-learning projects by working together...I have experienced it many times..." (Respondent no. 3).

Three more teachers expressed that insufficient service-learning participation on the part of stakeholders and lack of administrative support leads to failure of service-learning implementation. For example, one of them mentioned: 
I have experienced that the lack of management support and community involvement through shared understanding and collaboration leads to failure of service-learning ... I suggest (there is) a dire need for proper collaboration. (Respondent no. 28).

Likewise, other teachers also opined that equal involvement of all participants in the process of service-learning activity was important. Further, they uttered that the success of servicelearning was dependent on the collective participation of the stakeholders. In the view of Respondent no. 16 service-learning implementation was an expensive, arduous, and challenging activity. This purports that several issues were hampering the process of implementation such as funding, monitoring, and lack of community ownership. However, besides, majority of the teachers suggested that collaboration was the key to the success of the service-learning activity and all participants needed to develop closer understanding and linkage for implementing the service-learning activity.

In this study, we noticed that all teachers had the belief that collaboration was necessary for the successful implementation of a service-learning project. They [teachers] suggested that the gap between community and institutions could be bridged through the development of positive working relationships and a sense of ownership among all the participants. Furthermore, they [teachers] also suggested that all stakeholders of the service-learning should have equal opportunity in the decision-making process and openly giving their views for the better implementation of a service-learning project.

\subsection{Reflection}

Teachers mentioned that reflection was an essential component of service-learning. They uttered that reflection plays a key role in the success of a service-learning activity because it is directly related to students' learning. The majority of the teachers were of the view that reflection creates a link between classroom goals and objectives and students' community exposure. Specifically, this aspect was emphasized by few teachers and stated that reflection promotes students' critical thinking during service-learning-one of the major goals of vocational education. Through reflection, during service-learning, the learning experience of students is enriched. For example, one of the teachers said:

Well! When the students are placed in a community context, they interact with other people and get new experiences ... this enables them to think deeply and share their ideas with others. Hmmm! I believe that this is a very important aspect (of service-learning) because it leads to students' perspective transformation. (Respondent no. 17).

Other teachers also shared similar views that placement of students in a community context could help them learn new norms and would enable them to critically relate their own experiences with others. It was a process of reflectivity that ignites their interest to explore issues in the community and suggest solutions. We found that many teachers viewed that when students participate and reflect on their service-learning experience it helps them to develop skills for community action and involvement as active citizens. Further, some teachers believed that reflection helps students to link course content with service activities in which students were involved. For example, a teacher said: 
I think when we provide students an opportunity to think, they become critical and they explore and understand their assumptions about their role in the community as citizens. They know to solve community problems and become active participants in community life. (Respondent no. 3).

Reflections provide an opportunity for meaningful interaction between students' experiences and their contributions. To ensure reflexivity, students have to closely examine different issues during service-learning that occur in the community life of other people and bring about a meaningful change in their own lives, said two teachers. One teacher remarked, students reflect on their social background, race, ethnicity, religion, and gender. They try to see the importance which is attached with the relationships in which they [students] are involved and create their own identity based on explorations in the community.

Table-1: Themes, key concepts, and supporting quotes (teachers' perspectives)

\begin{tabular}{|c|c|c|}
\hline Themes & Key concepts & Supporting quotes \\
\hline$\stackrel{\stackrel{\infty}{\Xi}}{\stackrel{\Xi}{\Xi}}$ & $\begin{array}{l}\text { - All stakeholders must participate in } \\
\text { the planning stage } \\
\text { - There is a centralized planning } \\
\text {-Role of students is limited to } \\
\text { providing service in the community } \\
\text {-Teachers not encouraged in the } \\
\text { planning for service-leaning } \\
\text {-Community members are unaware } \\
\text { of how service-learning planning is } \\
\text { done. }\end{array}$ & $\begin{array}{l}\text { - "Students don't have any role in service- } \\
\text { learning planning. They should have enough } \\
\text { knowledge about planning, but they are not } \\
\text { allowed to take part in the planning process". } \\
\text { Respondent } 8 \text {. } \\
\text { - "teachers should know about all of the aspects } \\
\text { of the service-learning activity. This would only } \\
\text { be possible if they are given a chance to } \\
\text { participate in the planning stage." Respondent } 25 . \\
\text { - "community members and students are also } \\
\text { passive recipients during the service-learning } \\
\text { implementation." Respondent } 14 \text {. }\end{array}$ \\
\hline 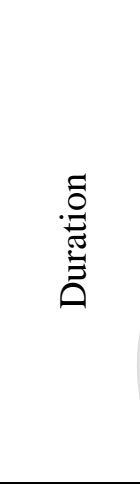 & $\begin{array}{l}\text { - Service-learning duration is } \\
\text { important and needs to be increased. } \\
\text { - Service-learning was a time- } \\
\text { consuming activity } \\
\text { - Time duration for service activity } \\
\text { should be increased } \\
\text { - Students needs to have more time } \\
\text { to reflect and learn from their service } \\
\text { activities } \\
\text { - Current duration for service } \\
\text { activity was not enough }\end{array}$ & $\begin{array}{l}\text {-"actually service-learning is challenging, So the } \\
\text { duration needs to be increased" Respondent } 4 . \\
\text { "The current duration seems insufficient. I } \\
\text { suggest the duration should be increased. This } \\
\text { will benefit both the community and students." } \\
\text { Respondent } 27 \text {. } \\
\text { - "I believe more time provides more benefits to } \\
\text { students. They need to prepare their service kits, } \\
\text { arrange their trip to the target community and } \\
\text { later write the reflections". Respondent } 28 \text {. }\end{array}$ \\
\hline 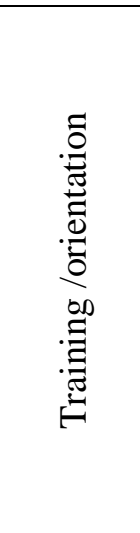 & $\begin{array}{l}\text { - training was important for all } \\
\text { service partners } \\
\text { - service-learning participants need } \\
\text { to be properly trained and oriented } \\
\text { with the implementation procedures } \\
\text { - there are no ongoing training and } \\
\text { orientation before a service-learning } \\
\text { project is launched } \\
\text { - there is no proper training or } \\
\text { orientation for students and } \\
\text { community members on service- } \\
\text { learning }\end{array}$ & $\begin{array}{l}\text { - "There are many problems related to students' } \\
\text { service performance and community support." } \\
\text { Respondent } 19 . \\
\text { - "There should be training for students and } \\
\text { community members so that they can perform } \\
\text { their roles effectively." Respondent } 12 \text {. } \\
\text { - "the current service-learning is conducted } \\
\text { without proper orientation for the students, } \\
\text { community members or faculty. The students } \\
\text { cannot participate in the service-learning } \\
\text { actively." Respondent } 2 \text {. }\end{array}$ \\
\hline
\end{tabular}




\begin{tabular}{|c|c|c|}
\hline & $\begin{array}{l}\text { - Students are placed in the } \\
\text { community for service-learning } \\
\text { without the need for analysis } \\
\text { - placement of students should be } \\
\text { decided based on collaboration with } \\
\text { the community, consultation with } \\
\text { faculty, and student' own opinion } \\
\text { - before placement of students in a } \\
\text { community, the targeted community } \\
\text { members need to be advised about } \\
\text { the unexpected challenges that might } \\
\text { occur in the community, the } \\
\text { procedures, and the methods used to } \\
\text { perform the activity }\end{array}$ & $\begin{array}{l}\text { - "The community members should have a voice, } \\
\text { and that they should be taken into consideration, } \\
\text { before sending students for service activity which } \\
\text { was missing in the student placement practice." } \\
\text { Respondent } 9 . \\
\text { - "the target community is not taken into } \\
\text { confidence about the placement of students." } \\
\text { Respondent } 5 \text {. } \\
\text { - "before service site placement, the community } \\
\text { members are not properly informed about the } \\
\text { purpose and aims of the service activity." } \\
\text { Respondent } 1 .\end{array}$ \\
\hline 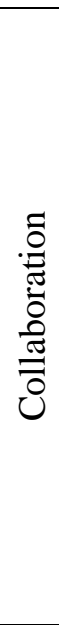 & $\begin{array}{l}\text { - service-learning was affected by a } \\
\text { lack of collaboration among the } \\
\text { stakeholders } \\
\text { - the collaboration gap between the } \\
\text { community, faculty, and students } \\
\text { was widening day by day } \\
\text { - the community did not see any } \\
\text { visible benefits in the service- } \\
\text { learning, hence they were recipients } \\
\text { and customers of service, rather than } \\
\text { participants and partners }\end{array}$ & $\begin{array}{l}\text {-"There is a lack of closer cooperation between } \\
\text { the community and the institution". Respondent } \\
6 . \\
\text {-"There is insufficient participation from } \\
\text { community members and lack of administrative } \\
\text { support that affects the implementation process". } \\
\text { Respondent } 24 \text {. } \\
\text {-"Participation rate of community in the service- } \\
\text { learning activity was rapidly decreasing, because } \\
\text { of lack of collaboration and trust". Respondent } \\
20 . \\
\text {-"there is a poor collaboration between the } \\
\text { community and administration during the } \\
\text { service-learning". Respondent } 8 \text {. }\end{array}$ \\
\hline  & $\begin{array}{l}\text { - reflection is an important element } \\
\text { of service-learning } \\
\text { - students must write reflections on } \\
\text { their service activity as it contributes } \\
\text { to their learning } \\
\text {-reflection improves critical thinking } \\
\text { and learning skills among students } \\
\text { during service-learning }\end{array}$ & $\begin{array}{l}\text {-"The time for reflection on the service-learning } \\
\text { activity needs to be enhanced". Respondent } 3 \text {. } \\
\text {-"in most cases, students did not meet the } \\
\text { required service reflections. Therefore, they don't } \\
\text { understand what they did and why they did it." } \\
\text { Respondent } 15 \text {. } \\
\text {-"there is a lack of proper guidance and support } \\
\text { to students during the service-learning activity } \\
\text { for writing reflections". Respondent } 8 \text {. } \\
\text { - "there is a clear need to improve the process } \\
\text { and practice of reflections for students. The types } \\
\text { of reflection activities should be practiced in the } \\
\text { current service-learning for student } \\
\text { development." Respondent } 10 \text {. }\end{array}$ \\
\hline
\end{tabular}

\section{Discussion}

This study identified planning, duration, training, and orientation, students' placement, collaboration, and reflection as key factors influencing service-learning implementation in the Pakistani context. The findings of this study are very important as previous research has not yet revealed such complex perspectives on the experiences of teachers with service-learning implementation, specifically in the context of Pakistan. One important theme that emerged from this research was planning. The participants suggested that planning played a key role in service-learning implementation. Previous research has also highlighted planning to be an 
important element of service-learning (Bringle \& Hatcher, 1996). Service-learning researchers have also emphasized that effective planning was needed for service-learning activity (Zhang et al., 2011). In this study, training and orientation emerged as another important factor. A former study has indicated that ongoing training on service-learning may help in shifting the balance towards increased dedication to service-learning (Bringle et al., 2012). Students' placement emerged yet another important theme in this study. Teachers believed that students' needed to be oriented with community needs, cultural context, sensitivities before sending them for service-learning activity in a community site. Teachers demonstrated their feelings that community need analysis would positively impact service-learning implementation. Positive student outcomes have been shown in numerous earlier service-learning studies (Anderson, 2000; Bringle \& Hatcher, 1995; Howard, 2003) related to student service-learning placement. However, there is a lack of studies on the perceptions and experiences of teachers about student outcomes who participate in service-learning from the context of vocational education, specifically in Pakistan.

This study found a clear lack of collaboration among the participants in the service-learning project. Most of the teachers emphasized the need and practice of collaboration among all the stakeholders during the service-learning project. Surprisingly, though, teachers did not express confidence related to the collaboration element of service-learning rather they [teachers] favoured the idea of collaboration and argued that it would further improve the confidence of the community in the service that they receive. Research study has termed collaboration an important element of service-learning (King, 2004). Reflection on service-learning was another significant theme that emerged through this study. Teachers demonstrated that reflection added to students' learning and intellectual growth. Former studies (Hatcher \& Bringle, 1997; Hatcher et al., 2004) have also shared numerous benefits of reflection for students ranging from improving critical thinking skills to making informed decisions. The teachers argued that the lack of flexible duration during service-learning made it difficult for students to focus on learning in the absence of reflection. Hence, according to them a key aspect of the successful service-learning implementation was critical and meaningful reflection. Teachers participating in this study seemed more concerned about lack of active reflections during service-learning implementation and suggested for more time and resources to do variety of reflective sessions with students to get maximum benefits out of service-learning activity.

This study identified that these above-mentioned factors have been overlooked during the service-learning implementation of service-learning. Contrary to this finding, previous research studies of (Rue, 1996; Furco \& Billing 2002; Butin, 2010; Phillips, 2011) have stressed mutual collaboration among all partners during the process of the service-learning activity. They believed that better planning and review of previous experiences was essential to design and implement quality service-learning. This study further discovered that service duration was another important factor that influenced service-learning implementation in vocational training institutes of Pakistan. This finding is not in line with previous research findings. For example, Rue (1996) and Furco and Billing (2002) strongly support the creation of a supportive climate for service implementation. Similarly, Jeandron and Robinson (2010) have suggested designing a service-learning activity where all the participants should work together and facilitate each other based on mutual collaboration. The views are shared by Bringle and Steinberg (2010) and Phillips (2011) as well who state that all stakeholders should equally participate in the process of service-learning by reciprocally exchanging, cooperating, and collaborating during service-learning implementation. The existing duration allocated for the service-learning course was not sufficient. On the other hand, many service-learning 
researchers have recommended more time for service activity. For example, Lambright and Lu (2009) have shared similar views suggesting that duration is an important element and it should be flexible enough to meet the requirements of student learning and development needs.

The current study further explored that the implementation of service-learning in vocational training institutes in Pakistan was also influenced by other factors such as reflection, support, and training as well as placement. This shows that these aspects were not properly taken into account during the process of service-learning implementation. On the contrary, many researchers have termed these important elements of service-learning activity. For example, Butin (2010) has reported that irrespective of the fact whether the service-learning course is compulsory or optional, management support is a key to the sustainability of service-learning. Butin (2010) also lays stress on designing and doing quality reflection by the students during service-learning. Similarly, Salam et al. (2019) found that the placement of students should be decided based on mutual understanding and collaboration with the community, consultation with faculty and student. This means that the existing service-learning implementation in vocational training institutes of Pakistan (Punjab in specific) has been overlooked. This finding is not in line with the results of previous studies because earlier researchers such as Falk, (2012), King (2004), Jacoby (2014), Lieberman (2014), Howard (2003) have argued that successful service-learning programs have clear vision and mission that guide the implementers throughout the service activity. In this regard, Butin's (2010) assertion seems logical that service-learning implementation must be institutionalized based on institutional philosophy, mission, and long-term plans.

\section{Conclusion}

Based on the above-mentioned analysis, it can be concluded that the existing service-learning implementation in vocational training institutes needed improvement to effectively meet the local needs. The service-learning program has many loopholes which need to be resolved such as lack of clear vision and mission, lack of need analysis of the community site or context before launching a service project, insufficient training and orientation for all stakeholders, poor collaboration among the participants like students, faculty, community, and management in all stages of the service-learning design, planning and evaluation, lack of proper student placement in community site for service activity, insufficient service duration, lack of motivation for service activity, weak partnership concept, poor reciprocity approach, gender imbalance, and weak program evaluations. The respondents were interviewed at length on the service-learning program and its response to the needs of students, teachers, and the community. The results showed that there is a clear indication to bring about major changes in the service-learning implementation and to cater to the existing local needs, achieve the goals and aims of development of students and communities by addressing the above-mentioned issues in the context of vocational training institutes of Pakistan.

\subsection{Suggestions}

In the context of vocational education, this study demonstrated that the process of implementation was plagued by different factors such as planning, duration, training and orientation, student placement, collaboration, and reflection. For extracting maximum benefits from service-learning implementation, the duration must be increased so that students and teachers may extend their full dedication and potential to provide service to the target community. Based on the results, it is suggested that vocational educators may consider the 
crucial aspect of students' placement during service-learning. There must be comprehensive community need analysis before students' placement in the community site and they need to be sensitized towards sensitive issues like security, cultural issues, social behaviors, and community dynamics. The management of vocational institutes must focus on effective collaboration during service-learning. This is a significant factor that deeply affects the success of the service-learning program. Vocational educators need to consider hands-on lessons from the community interaction and provide students meaningful opportunities to carry out reflections on the service-learning activity. Service-learning interventions must provide students with reflection opportunities to achieve the goals of service-learning which is purely academic and focused on student development. This study has some limitations, therefore the results of this study needed to be validated in other contexts.

\subsection{Future Direction}

This study looked at the perspectives of teachers about the factors influencing service-learning implementation in vocational education institutes of Pakistan. It is recommended that future research should explore the perspectives of the community about the factors influencing service-learning implementation in the context of vocational training institutes or elsewhere. This will provide a clearer picture of the issues involved in service-learning implementation from the community point of view. This will lead to new insights and understanding about service-learning implementation and its outcomes, its benefits, and issues involved from a new perspective. This will also open new avenues and vistas for future research in the field of service-learning in the context of vocational education and general education.

\section{References}

Akhtar, A., Topping, K., Tariq, R. H., \& Wakefield, P. (2011). Entrepreneurial propensity in Pakistan and UK: A comparative study of Pakistani and UK prospective teachers. Pakistan Journal of Commerce and Social Sciences, 5(2), 243-265. https://www.econstor.eu/handle/10419/188028

Anderson, J. B. (2000). Learning in deed: Service-learning and preservice teacher education. Service Learning, $\quad$ General, $16(1), \quad$ 1-17. https://digitalcommons.unomaha.edu/slceslgen/16

Berman, S. (2006). Service-learning: A guide to planning, implementing, and assessing student projects. Thousand Oaks.

Blakey, J. M., Theriot, S., Cazzell, M., and Sattler, M. (2015). Is service-learning worth it?: A mixed-methods study of faculty's service-learning experiences. The International Journal of Research on Service-Learning and Community Engagement, 3(1), 1-19. https://core.ac.uk/reader/236087450

Bringle, R. G., and Hatcher, J. A. (1995). A service-learning curriculum for faculty. Michigan Journal of Community Service Learning, 2(1), 112-122. https://scholarworks.iupui.edu/handle/1805/4591

Bringle, R. G., and Hatcher, J. A. (1996). Implementing service learning in higher education. The Journal of Higher Education, 67(2), 221-239. https://doi.org/10.2307/2943981

Bringle, R. G., and Hatcher, J. A. (2002). Campus-community partnerships: The terms of engagement. Journal of Social Issues, 58(3), 503-516. https://doi.org/10.1111/1540$\underline{4560.00273}$

Bringle, R. G., \& Steinberg, K. (2010). Educating for informed community involvement. 
American Journal of Community Psychology, 46(3), 428-441. https://doi.org/10.1007/s10464-010-9340-y

Bringle, R. G., Hatcher, J. A., and Jones, S. G. (2012). International service-learning: Conceptual frameworks and research. Stylus Publishing. https://doi.org/10.1177/1541344614549600

Brownell, J. E., and Swaner, L. E. (2010). Five high-impact practices: Research on learning outcomes, completion, and quality: Association of American Colleges and Universities. https://doi.org/10.1111/teth.12035

Butin, D. W. (2006). The Limits of Service-Learning in Higher Education. The Review of Higher Education, 29(4), 473-498. https://doi.org/10.1353/rhe.2006.0025

Butin, D. W. (2010). Service-learning in theory and practice: The future of community engagement in higher education. Palgrave Macmillan.

Creswell, J. W., and Clark, V. L. P. (2017). Designing and conducting mixed methods research. Sage.

Deeley, S. J. (2010). Service-learning: Thinking outside the box. Active Learning in Higher Education, 11(1), 43-53. https://doi.org/10.1177/1469787409355870

Denby, R. A. (2008). The impact of service-learning on students' sense of civic responsibility. Masters in Education, Faculty of Education, The University of Western Ontario, London. http://docplayer.net/5180079-The-impact-of-service-learning-on-studentssense-of-civic-responsibility-thesis-format-monograph-by-rebecca-a-denby-facultyof-education.html

Falk, A. (2012). Enhancing the team experience in service-learning courses. Journal for Civic Commitment, 18(1), 1-16. https://scholarworks.merrimack.edu/soe_facpub/1

Furco, A., and Billig, S. (2002). Service-learning: The essence of the pedagogy. Information Age.

Galvan, C., Meaney, K., \& Gray, V. (2018). Examining the reciprocal nature of servicelearning for underserved students and preservice teachers. Journal of Teaching in Physical Education, 37(4), 363-372. https://doi.org/10.1123/jtpe.2018-0051

Gershenson-Gates, R. (2012). The impact of service-learning on college students' civic development and sense of self-efficacy. College of Science and Health, Theses and Dissertations. DePaul University. https://via.library.depaul.edu/csh_etd/3

Hall, E., Chai, W., and Albrecht, J. A. (2016). A qualitative phenomenological exploration of teachers' experience with nutrition education. American Journal of Health Education, 47 (3), 136-148. https://doi.org/10.1080/19325037.2016.1157532

Hatcher, J. A., and Bringle, R. G. (1997). Reflection: Bridging the gap between service and learning. College Teaching, 45(4), 153-158. doi.org/10.1080/87567559709596221

Hatcher, J. A., Bringle, R. G., and Muthiah, R. (2004). Designing effective reflection: what matters to service-learning? Michigan Journal of Community Service Learning, 11(1), 38-46. http://hdl.handle.net/2027/spo.3239521.0011.104

Halberstadt, J., Schank, C., Euler, M., \& Harms, R. (2019). Learning sustainability entrepreneurship by doing: providing a lecturer-oriented service-learning framework. Sustainability, 11(5), 1217 $(1-22)$. https://doi.org/10.3390/su11051217

Howard, J. (2003). Service-learning research: Foundational issues. In: S.H. Billing, S. H and A. S. Waterman (eds) Studying Service-Learning: Innovations in Education Research Methodology, (pp. 1-12). Routledge.

Horning, M. L., Ostrow, L., Beierwaltes, P., Beaudette, J., Schmitz, K., and Fulkerson, J. A. 
(2020). Service-learning within community-engaged research: Facilitating nursing student learning outcomes. Journal of Professional Nursing, 36(6), 510-513. https://doi.org/10.1016/j.profnurs.2020.04.005

Huda, M., Jasmi, K. A., Alas, Y., Qodriah, S. L., Dacholfany, M. I., \& Jamsari, E. A. (2018). Empowering civic responsibility: Insights from service learning. In: S. L. Burton (Eds) Engaged Scholarship and Civic Responsibility in Higher Education (pp. 144165). IGI Global. https://doi.org/10.4018/978-1-5225-3649-9.ch007

Jacoby, B. (1996). Service-Learning in Today's Higher Education. In: B. Jacoby, \& Associates (Eds.), Service-learning in higher education: Concepts and practices (pp. 3-25). Jossey-Bass.

Jacoby, B. (2014). Service-learning essentials: Questions, answers, and lessons learned. John Wiley \& Sons.

Jeandron, C., and Robinson, G. (2010). Creating a climate for service learning success. American Association of Community Colleges. https://files.eric.ed.gov/fulltext/ED513943.pdf

Jerome, L. (2012). Service learning and active citizenship education in England. Education, $\begin{array}{llll}\text { Citizenship and Social } & \text { Justice, } & \text { 7(1), }\end{array}$ https://doi.org/10.1177\%2F1746197911432594

Johnson, M., Goldberg, C., Willies-Jacobo, L., Wan, L., Guluma, K., \& Smith, S. (2019). Implementation and outcomes of a community assessment service-learning activity within academic learning communities. Journal of Medical Education and Curricular Development, 6, 1-6. https://doi.org/10.1177/2382120519864403

King, J. T. (2004). Service-learning as a site for critical pedagogy: A case of collaboration, caring, and defamiliarization across borders. Journal of Experiential Education, 26 (3), 121-137. https://doi.org/10.1177\%2F105382590402600304

Lambright, K. (2008). Lessons outside of the classroom: Examining the effectiveness of service learning projects at achieving learning objectives. Journal of Public Affairs Education, 14(2), 205-217. https://doi.org/10.1080/15236803.2008.12001520

Lambright, K. T., and Lu, Y. (2009). What Impacts the learning in service-learning? An examination of project structure and student characteristics. Journal of Public Affairs Education, 15(4), 425-444. https://doi.org/10.1080/15236803.2009.12001570

Lee, S. J., Wilder, C., \& Yu, C. (2018). Exploring students' perceptions of service-learning experiences in an undergraduate web design course. Teaching in Higher Education, 23(2), 212-226. https://doi.org/10.1080/13562517.2017.1379486

Lieberman, D. (2014). The ABCDs of service-learning: Who is serving whom? Journal of Higher Education Outreach and Engagement, 18(4), 7-16. https://openjournals.libs.uga.edu/jheoe/article/view/1155/1154

Lincoln, Y. S., and Guba, E. G. (1985). Naturalistic inquiry (Vol. 75). Sage.

Michael, R. D., Webster, C. A., Egan, C. A., Stewart, G., Nilges, L., Brian, A., ... \& Vazou, S. (2018). Viability of university service learning to support movement integration in elementary classrooms: Perspectives of teachers, university students, and course instructors. Teaching and Teacher Education, 72(1), 122-132. https://doi.org/10.1016/j.tate.2018.03.003

Moustakas, C. E. (1994). Phenomenological research methods. Sage.

O'Grady, C. R. (2014). Integrating service learning and multicultural education in colleges and universities. Routledge.

Phillips, D. C., \& Burbules, N. C. (2000). Philosophy, theory, and educational research: Postpositivism and educational research. Rowman \& Littlefield. 
Phillips, J. M. (2011). Integrating service-learning into the classroom: Examining the extent to which students achieve course objectives and a sense of civic responsibility by engaging in service learning (Order No. 3472928). ProQuest Dissertations \& Theses Global. (894264125). https://search.proquest.com/dissertations-theses/integratingservice-learning-into-classroom/docview/894264125/se-2?accountid=27795

Playford, D., Bailey, S., Fisher, C., Stasinska, A., Marshall, L., Gawlinski, M., \& Young, S. (2019). Twelve tips for implementing effective service learning. Medical Teacher, 41(1), 24-27. https://doi.org/10.1080/0142159X.2017.1401217

Robinson, G. and Gottlieb, K. (2002). Civic responsibility and service-learning: The need for curricular integration. https://www.mesacc.edu/community-civicengagement/journals/civic-responsibility-and-service-learning-need-curricular.

Rue, P. (1996). Administering successful service-learning programs. In: B. Jacoby (Ed.), Service learning in higher education (pp. 246-275). Jossey-Bass.

Salam, M., Iskandar, D. N. A., Ibrahim, D. H. A., \& Farooq, M. S. (2019). Service-learning in higher education: A systematic literature review. Asia Pacific Education Review, 20(4), 573-593. https://doi.org/10.1007/s12564-019-09580-6

Sangpikul, A. (2017). Implementing academic service learning and the PDCA cycle in a marketing course: Contributions to three beneficiaries. Journal of Hospitality, Leisure, Sport \& Tourism Education, 21(1), 83-87. https://doi.org/10.1016/j.jhlste.2017.08.007

Schamber, J. F., and Mahoney, S. L. (2008). The development of political awareness and social justice citizenship through community-based learning in a first-year general education seminar. The Journal of General Education, 57(2), 75-99. https://www.jstor.org/stable/27798097?seq=1

Trigos-Carrillo, L., Fonseca, L., \& Reinoso, N. (2020). Social impact of a transformative service-learning experience in a post-conflict setting. Frontiers in Psychology, 11 (47), 1-12. https://doi.org/10.3389/fpsyg.2020.00047

Uzair-ul-Hassan, M., \& Noreen, Z. (2013). Educational mismatch between graduates possessed skills and market demands in Pakistan. International Education Studies, 6(11), 122129. https://doi.org/10.5539/ies.v6n11p122

Wade, R. (2008). Service-learning. In: L. S. Levstik \& C. A. Tyson (Eds), Handbook of research in social studies education, (pp. 109-123). Routledge.

Weiler, L., Haddock, S., Zimmerman, T. S., Krafchick, J., Henry, K., and Rudisill, S. (2013). Benefits derived by college students from mentoring at-risk youth in a servicelearning course. American Journal of Community Psychology, 52(3-4), 236-248. https://doi.org/10.1007/s10464-013-9589-z

Zhang, G., Zeller, N., Griffith, R., Metcalf, D., Williams, J., Shea, C., and Misulis, K. (2011). Using the context, input, process, and product evaluation model (CIPP) as a comprehensive framework to guide the planning, implementation, and assessment of service-learning programs. Journal of Higher Education Outreach and Engagement, 15(4), 57-84. https://openjournals.libs.uga.edu/jheoe/article/view/901 


\section{Appendix 1: Semi-structured interview guide}

1. Name

2. Age-

3. Name of vocational training institute

4. Total teaching experience in service-learning

Main questions:

a. How do you describe your experience in the service-learning project?

b. Do you think the duration of the service-learning project was sufficient? How?

c. Do you think the service-learning curriculum meets the requirements of students? How?

d. Do you think through service-learning needs of the communities were effectively addressed? How?

e. How do you describe the effect of service-learning on students' learning?

f. What problems/issues do you think exist in the implementation of service-learning?

\section{Appendix 2: $\quad$ Participants' profile}

\begin{tabular}{|c|c|c|c|c|c|}
\hline $\begin{array}{l}\text { S. } \\
\text { No. }\end{array}$ & Name (pseudo name) & Gender & $\begin{array}{l}\text { Age in } \\
\text { Years }\end{array}$ & $\begin{array}{l}\text { Place of vocational } \\
\text { training institute }\end{array}$ & $\begin{array}{l}\text { Total service-learning } \\
\text { experience in years }\end{array}$ \\
\hline 1 & Rashid Dhodial & M & 35 & Bhawalnagar & 3 \\
\hline 2 & Akram Chaudhry & M & 39 & Bahwalpur East & 2 \\
\hline 3 & Riaz Bashir & M & 29 & Bahwalpur (F) & 3 \\
\hline 4 & Munshi Waraich & M & 42 & Bahwalpur (M) & 3 \\
\hline 5 & Abdul Hamid Dogar & M & 39 & Bhakar & 2 \\
\hline 6 & Shahid Ilyas & M & 30 & Chiishtian & 1 \\
\hline 7 & Mohammad Irfan & M & 28 & Chowk Azam & 2 \\
\hline 8 & Shiraz Majeed & M & 30 & Dhajal & 3 \\
\hline 9 & Munawar Said Arif & M & 29 & Darya Khan & 2 \\
\hline 10 & Tahweez Noushad & $\mathrm{M}$ & 25 & Dhera Ghazi Khan & 3 \\
\hline 11 & Bashirullah & M & 27 & Dunyapur & 2 \\
\hline 12 & Irfan Bashir & M & 32 & Fatehpur & 2 \\
\hline 13 & Aneesul Hassan & M & 33 & Fazilpur & 2 \\
\hline 14 & Arifullah & M & 31 & Fort Abbas & 3 \\
\hline 15 & Asad Riaz Gujar & M & 35 & Jamal Din Wali & 3 \\
\hline 16 & Shaheed Murad & M & 35 & Jampur & 2 \\
\hline 17 & Asif Danish & M & 36 & Jatoi & 1 \\
\hline 18 & Sultan Murad & M & 37 & Kahror Pakka & 2 \\
\hline 19 & Sohail Akram & M & 27 & Kallur Kot & 3 \\
\hline 20 & Mohmmad Arif & M & 28 & Khanpur & 3 \\
\hline 21 & Shawkat Hameed & M & 33 & Khanbela & 2 \\
\hline 22 & Sardar Nabi Shah & M & 25 & Khanewal & 1 \\
\hline 23 & Mohmmad Bashir & M & 24 & Kot Addu & 2 \\
\hline 24 & Chaudhry Nawab & M & 27 & Kot Mittan & 2 \\
\hline 25 & Rehmat Niaz & M & 27 & Kot Sultan & 2 \\
\hline 26 & Ayaz Irshad & M & 37 & Layya & 3 \\
\hline 27 & Ahsan Chaudhry & M & 37 & Liaqat Pur & 1 \\
\hline 28 & Sohrab Gugar & M & 42 & Lodhran & 2 \\
\hline 29 & Danish Akram & M & 40 & Lodhan & 3 \\
\hline 30 & Siraj Munir Raja & M & 34 & Khanpur & 3 \\
\hline
\end{tabular}

